\title{
PERKEMBANGAN POLITIK HUKUM \\ PERTANGGUNGJAWABAN PARTAI POLITIK \\ DALAM PENGELOLAAN BANTUAN KEUANGAN NEGARA \\ PASCA REFORMASI
}

\author{
Torang Rudolf Effendi Manurung \\ Mahasiswa Program Studi Doktor IImu Hukum Universitas Diponegoro (UNDIP) \\ Email: torang_hukum@yahoo.co.id
}

\begin{abstract}
The politic party is a democration tool at any country which function for to channel populace aspiration to government, to give politic education, and another. In other to function get materialized, so country was giving help finance for to help the politic party in the it operation activity. Politic party in to manage help finance from country must justify to the country building on law, so the law must made by country pass legal policy. Legal policy responsibility politic party in management help country finance is a formal policy of country for attain national destination by law. For attain national destination mentioned, so to do law making as legislation and technical regulation which arrange responsibility mentioned. Pasca reformation, legal policy experience development arrangement aspect. The development perceivable direct general election implementation period on the Indonesian Republic that is general election 2004 years, 2009 years, and 2014 years. In third general election implementation mentioned law products type for arrange responsibility politic party in management help country finance.
\end{abstract}

Keyword: legal policy, politic party, help country finance of responsibility.

\begin{abstract}
Abstrak
Partai politik adalah salah satu alat demokrasi di negara manapun yang berfungsi untuk menyalurkan aspirasi rakyat kepada pemerintah, memberikan pendidikan politik, dan lain-lain. Agar fungsi itu dapat terwujud, maka negara memberikan bantuan keuangan untuk membantu partai politik di dalam menjalankan kegiatannya. Partai politik dalam mengelola bantuan keuangan dari negara wajib mempertanggungjawabkan kepada negara berdasarkan hukum, maka hukum harus dibuat oleh negara melalui politik hukum. Politik hukum pertanggungjawaban partai politik dalam pengelolaan bantuan keuangan negara adalah suatu kebijakan resmi negara untuk mencapai tujuan nasionalnya melalui hukum. Untuk mencapai tujuan nasional tersebut, maka dilakukan pembuatan hukum berupa peraturan perundang-undangan dan peraturan teknis yang mengatur pertanggungjawaban tersebut. Pasca reformasi politik hukumnya mengalami perkembangan dari aspek pengaturan. Perkembangan itu dapat dipahami menurut periodisasi penyelenggaraan pemilu secara langsung di Negara Republik Indonesia, yaitu: Pemilu 2004, 2009, dan 2014. Dalam ketiga penyelenggaraan pemilu tersebut terbentuk produk-produk hukum untuk mengatur pertanggungjawaban partai politik dalam pengelolaan bantuan keuangan.
\end{abstract}

Kata kunci: Politik Hukum, Partai Politik, Pertanggungjawaban Bantuan Keuangan Negara.

\section{A. Pendahuluan}

Partai politik tidak hanya menjadi saluran partisipasi politik warga negara, tetapi juga untuk mengintegrasikan para individu dan kelompok dalam masyarakat ke dalam sistem politik. Partai politik tidak hanya berperan dalam mempersiapkan para kader calon pemimpin bangsa untuk dicalonkan melalui pemilihan umum (pemilu) untuk menduduki berbagai jabatan dalam

118 Yustisia. Vol.4 No.1 Januari - April 2015 lembaga legislatif atau eksekutif, tetapi juga memperjuangkan kebijakan publik berdasarkan aspirasi dan kepentingan masyarakat. Untuk itu partai politik memerlukan sumberdaya agar dapat bertahan dan mengoperasikan struktur dasar partai untuk merepresentasi rakyat, mengembangkan kapasitas bersaing dalam pemilu, dan berkontribusi secara kreatif dalam perdebatan kebijakan publik. Proses politik demokratis tidak akan dapat berlangsung tanpa sumber keuangan. Tanpa

Perkembangan Politik Hukum .... 
dana yang memadai, partai politik tidak akan dapat mengorganisasi dirinya, para politikus tidak akan dapat berkomunikasi dengan publik, dan kampanye pemilu tidak akan dapat dilaksanakan. Singkat kata, partai politik memerlukan dana yang cukup besar untuk dapat melaksanakan fungsinya, baik sebagai jembatan antara masyarakat dengan negara maupun sebagai peserta pemilu. Berdasarkan pengalaman negara demokrasi di dunia, terdapat tiga alternatif sumber dana partai politik (Sidik Pramono, 2011: 3\&49). Pertama, dari internal partai, seperti iuran anggota, sumbangan dari kader partai yang duduk dalam lembaga legislatif atau eksekutif, dan badan usaha yang didirikan oleh partai. Pada mulanya semua kebutuhan keuangan partai politik dipenuhi oleh iuran anggota. Hubungan ideologis kuat antara partai politik dengan anggota menyebabkan partai politik tidak sulit menggalang dana dari anggota. Namun sejalan dengan perubahan struktur sosial masyarakat dan penataan sistem pemerintahan demokrasi yang semakin kompleks, kini nyaris tidak ada partai politik yang hidup sepenuhnya dari iuran anggota (Didik Supriyanto, 2012: 154). Kedua, dari kalangan swasta (private funding), seperti sumbangan dari individu (termasuk dari orang kaya, keluarga kaya), badan usaha swasta, organisasi (seperti organisasi lobi), dan kelompok masyarakat. Dan ketiga, dari negara (public funding), yaitu dari Anggaran Pendapatan dan Belanja Negara (APBN) dan Anggaran Pendapatan dan Belanja Daerah (APBD) baik yang dialokasikan secara langsung maupun secara tidak langsung kepada partai politik. Bantuan negara kepada partai politik ini merupakan hal wajar, karena hampir semua negara memberikan subsidi kepada partai politik. Misalnya Jerman, Amerika Serikat, Portugal, Ceko, Inggris, Afrika Selatan, dan Filipina (Emmy Hafild, 2008: 14).

Di Negara Republik Indonesia, partaipartai politik yang memenuhi ambang batas suara (electoral threshold) dan memiliki kursi (parliamentary threshold) di Dewan Perwakilan Rakyat (DPR) dan Dewan Perwakilan Rakyat (DPRD) mendapatkan bantuan keuangan dari negara, baik Anggaran Pendapatan Dan Belanja Negara (APBN) maupun Anggaran Pendapatan Dan Belanja Daerah (APBD).

Bantuan keuangan negara ini memiliki akibat hukum, yakni adanya kewajiban mempertanggungjawabkan pengelolaan bantuan keuangan negara berdasarkan peraturan perundang-undangan yang berlaku. Oleh karena itu, negara membentuk hukum berupa peraturan perundang-undangan yang mengatur pertanggungjawaban partai politik dalam mengelola bantuan keuangan negara. Tindakan negara untuk membentuk hukum tersebut disebut politik hukum. Pasca reformasi politik hukum pertanggungjawaban partai politik dalam mengelola bantuan keuangan negara ditandai dengan penyelenggaraan Pemilu 2004, 2009, sampai 2014. Ketiga periode penyelenggaraan Pemilu tersebut masing-masing memiliki jumlah partai politik yang berbeda-beda. Berbagai produk peraturan perundang-undangan dihasilkan pada ketiga periode penyelenggaraan Pemilu untuk mengatur pertanggungjawaban partai politik sebagai peserta Pemilu dalam mengelola bantuan keuangan yang diperoleh dari negara. Oleh karena itu, masalah yang dapat dirumuskan adalah bagaimana perkembangan politik hukum pertanggungjawaban partai politik dalam mengelola bantuan keuangan negara pasca reformasi jika ditinjau dari penyelenggaraan Pemilu 2004, 2009, dan 2014?

\section{B. Konsep Partai Politik}

Dengan meluasnya gagasan bahwa rakyat harus ikut serta dalam proses politik maka parpol telah lahir, dan berkembang menjadi penghubung antara rakyat dan pemerintah. Bahkan partai politik dianggap sebagai lambang negara modern. Oleh karena itu, hampir semua negara memiliki partai politik (Ramlan Surbakti, 1999: 115).

Menurut Amal Ichlasul, bahwa Partai politik (selanjutnya disebut parpol) merupakan keharusan dalam kehidupan politik modern yang demokratis. Sebagai suatu organisasi, parpol secara ideal dimaksudkan untuk mengaktifkan dan memobilisasi rakyat, mewakili kepentingan tertentu, memberikan jalan kompromi bagi pendapat yang saling bersaing, serta menyediakan secara maksimal kepemimpinan politik secara sah (legitimate) dan damai (Amal Ichlasul, 1998: 11).

\section{Fungsi Dan Peranan Partai Politik}

Dalam kepustakan ilmu politik, sering dikemukakan bahwa partai politik mempunyai peranan (Amal Ichlasul, 1998: 11):

1. Dalam proses pendidikan politik;

2. Sebagai sumber rekrutmen para pemimpin bangsa guna mengisi berbagai macam posisi dalam kehidupan bernegara;

3. Sebagai lembaga yang berusaha mewakili kepentingan masyarakat, dan

4. Sebagai penghubung antar penguasa dan rakyat.

James Rosnau lebih menekankan pada fungsi parpol sebagai sarana penghubung antara 
berbagai macam kepentingan dalam suatu sistem politik. Dalam hal ini menurutnya ada dua peranan penting parpol dalam linkage politik, yakni (Abdul Mukthie Fadjar, 2008: 21-22):

1. Sebagai institusi yang berfungsi penetratif (penetrative linkage), dalam arti sebagai lembaga yang ikut memainkan peranan dalam proses pembentukan kebijakan negara;

2. Sebagai "reactive linkage", yaitu lembaga yang melakukan reaksi atas kebijakan yang dikeluarkan oleh negara.

Dengan demikian, dalam negara demokrasi modern, fungsi parpol secara umum adalah:

1. Sebagai sarana komunikasi publik, yaitu di satu pihak merumuskan kepentingan (interest articulation) dan menggabungkan atau menyalurkan kepentingan (interest agragation) masyarakat untuk disampaikan dan diperjuangkan kepada pemerintah, sedangkan di pihak lain juga berfungsi menjelaskan dan menyebarluaskan kebijaksanaan pemerintah kepada masyarakat (khususnya anggota parpol yang bersangkutan);

2. Sebagai sarana sosialisasi politik, yaitu proses di mana seseorang memperoleh pandangan, orientasi, dan niai-nilai dari masyarakat di mana dia berada. Proses tersebut juga mencakup proses di mana masyarakat mewariskan norma-norma dan nilai-nilai dari satu generasi ke generasi berikutnya. Melalui kursus-kursus pendidikan, parpol menanamkan nilai-nilai ideologi dan loyalitas kepada negara dan partai. Di NSB seperti Indonesia, yang bangsanya pada umumnya sangat plural, parpol dapat membantu peningkatan identitas nasional dan pemupukan integrasi nasional. Istilah sosialisasi politik (political socialization) merupakan istilah yang longgar pengertiannya, istilah yang ketat pengertiannya adalah pendidikan politik (political education), sedangkan yang paling ketat disebut indoktrinasi politik (political indoctrination).

3. Sebagai sarana rekrutmen politik (instrument of political recruitment), yakni proses melalui di mana partai mencari anggota baru dan mengajak orang yang berbakat untuk berpartisipasi dalam proses politik. Rekrutmen politik akan menjamin kontinuitas dan kelestarian partai, dan sekaligus merupakan salah satu cara untuk menyeleksi para calon pimpinan partai atau pemimpin bangsa.

Sebagai sarana mengatur konflik, yakni bahwa dalam negara demokratis yang masyarakatnya terbuka dan plural, perbedaan dan persaingan pendapat sangatlah wajar, akan tetapi sering menimbulkan konflik sosial yang sangat luas. Oleh karena itu, konflik harus bisa dikendalikan atau dijinakkan agar tidak berlarut-larut yang bisa mengoyahkan dan membahayakan eksistensi bangsa. Dalam hal ini parpol dapat berperan menekan konflik seminimal mungkin.

\section{Teori Politik Hukum}

Menurut Padmo Wahjono, bahwa politik hukum sebagai kebijakan dasar yang menentukan arah, bentuk maupun isi dari hukum yang akan dibentuk (Padmo Wahjono, 1986: 160). Definisi ini masih bersifat abstrak dan kemudian dilengkapi dengan sebuah artikelnya di majalah Forum Keadilan yang berjudul "Menyelisik Proses Terbentuknya Perundang-Undangan”. Dalam artikel tersebut Padmo Wahjono mengatakan bahwa politik hukum adalah kebijakan penyelenggara negara tentang apa yang dijadikan kriteria untuk menghukumkan sesuatu. Dalam hal ini kebijakan tersebut dapat berkaitan dengan pembentukan hukum, penerapan hukum dan penegakannya sendiri (Padmo Wahjono, 1991: 65).

Menurut Teuku Mohammad Radhie mendefinisikan politik hukum sebagai suatu pernyataan kehendak penguasa negara mengenai hukum yang berlaku di wilayahnya dan mengenai arah perkembangan hukum yang dibangun (Teuku Mohammad Radhie, 1973: 3).

Menurut Soedarto, bahwa politik hukum adalah kebijakan negara melalui badan-badan negara yang berwenang untuk menetapkan peraturanperaturan yang dikehendaki yang diperkirakan akan dipergunakan untuk mengekspresikan apa yang terkandung dalam masyarakat dan untuk mencapai apa yang dicita-citakan (Soedarto, 1983: 20).

Menurut Satjipto Rahardjo, bahwa politik hukum sebagai aktivitas memilih dan cara yang hendak dipakai untuk mencapai suatu tujuan sosial dan hukum tertentu dalam masyarakat. Di dalam studi politik hukum, menurut Satjipto Rahardjo, muncul beberapa pertanyaan mendasar yang muncul, yaitu: (1) tujuan apa yang hendak dicapai melalui sistem hukum yang ada? (2) cara-cara apa dan yang mana, yang dirasa paling baik untuk dipakai dalam mencapai tujuan tersebut? (3) kapan waktunya dan melalui cara bagaimana hukum itu perlu diubah? (4) dapatkah suatu pola yang baku dan mapan dirumuskan untuk membantu dalam memutuskan proses pemilihan tujuan serta cara-cara untuk mencapai tujuan tersebut dengan baik? (Satjipto Rahardjo, 1991: 352-353)

Perkembangan Politik Hukum .... 
Sunaryati Hartono tidak secara eksplisit merumuskan arti politik hukum. Namun, substansi pengertian darinya bisa ditangkap ketika dia menyebut hukum sebagai alat dan bahwa secara praktis politik hukum merupakan alat atau sarana dan langkah yang dapat digunakan oleh pemerintah untuk menciptakan sistem hukum nasional untuk mencapai cita-cita bangsa dan tujuan negara (Sunaryati Hartono, 1991: 1).

Menurut Moh. Mahfud MD, bahwa politik hukum adalah arahan atau garis resmi yang dijadikan dasar pijak dan cara untuk membuat dan melaksanakan hukum dalam rangka mencapai tujuan bangsa dan negara (Mahfud MD, 2010: 15).

\section{E. Perkembangan Politik Hukum Pertang- gungjawaban Partai Politik Dalam Pengelolaan Bantuan Keuangan Negara Pasca Reformasi}

Berangkat dari pemahaman politik hukum tersebut di atas, maka menurut penulis definisi politik hukum pertanggungjawaban partai politik dalam pengelolaan bantuan keuangan negara adalah suatu kebijakan hukum (legal policy) negara untuk mencapai tujuan nasionalnya dengan membentuk hukum berupa peraturan perundangundangan untuk mengatur pertanggungjawaban partai politik dalam mengelola bantuan keuangan negara. Pasca reformasi politik hukum tersebut menunjukkan perkembangan jika ditinjau dari periodisasi penyelenggaraan pemilu secara langsung di Negara Republik Indonesia, yaitu: Pemilu 2004, 2009, dan 2014.

Untuk lebih jelasnya dapat dilihat pada tabel di bawah ini:

\begin{tabular}{|c|c|c|}
\hline No. & $\begin{array}{c}\text { Periodisasi } \\
\text { Penyeleng- } \\
\text { garaan } \\
\text { Pemilu }\end{array}$ & $\begin{array}{c}\text { Nama-nama Partai } \\
\text { Politik Beserta Nomor } \\
\text { Urut }\end{array}$ \\
\hline 1. & Pemilu 2004 & $\begin{array}{ll}\text { 1. Partai Nasional } & \begin{array}{l}\text { Indonesia } \\
\text { Marhaenisme }\end{array} \\
\text { 2. Partai Buruh Sosial } \\
\text { Demokrat } \\
\text { 3. Partai Bulan Bintang } \\
\text { 4. Partai Merdeka } \\
\text { 5. Partai Persatuan } \\
\text { Pembangunan } \\
\text { 6. Partai Persatuan } \\
\text { Demokrasi } \\
\text { Kebangsaan } \\
\text { 7. Partai Perhimpunan } \\
\text { Indonesia Baru }\end{array}$ \\
\hline
\end{tabular}

Yustisia. Vol.4 No.1 Januari - April 2015

\begin{tabular}{|c|c|c|}
\hline No. & $\begin{array}{l}\text { Periodisasi } \\
\text { Penyeleng- } \\
\text { garaan } \\
\text { Pemilu } \\
\end{array}$ & $\begin{array}{c}\text { Nama-nama Partai } \\
\text { Politik Beserta Nomor } \\
\text { Urut }\end{array}$ \\
\hline & & $\begin{array}{l}\text { 8. Partai Nasional } \\
\text { Banteng } \\
\text { Kemerdekaan } \\
\text { 9. Partai Demokrat } \\
\text { 10. Partai Keadilan dan } \\
\text { Persatuan Indonesia } \\
\text { 11. Partai Penegak } \\
\text { Demokrasi Indonesia } \\
\text { 12. Partai Persatuan } \\
\text { Nahdlatul Ummah } \\
\text { Indonesia } \\
\text { 13. Partai Amanat } \\
\text { Nasional } \\
\text { 14. Partai Karya Peduli } \\
\text { Bangsa } \\
\text { 15. Partai Kebangkitan } \\
\text { Bangsa } \\
\text { 16. Partai Keadilan } \\
\text { Sejahtera } \\
\text { 17. Partai Bintang } \\
\text { Reformasi } \\
\text { 18. Partai Demokrasi } \\
\text { Indonesia Perjuangan } \\
\text { 19. Partai Damai } \\
\text { Sejahtera } \\
\text { 20. Partai Golongan } \\
\text { Karya } \\
\text { 21. Partai Patriot } \\
\text { Pancasila } \\
\text { 22. Partai Sarikat } \\
\text { Indonesia } \\
\text { 23. Partai Persatuan } \\
\text { Daerah } \\
\text { 24. Partai Pelopor }\end{array}$ \\
\hline 2. & Pemilu 2009 & $\begin{array}{ll}\text { 1. } & \text { Partai Hati Nurani } \\
& \text { Rakyat (Hanura) } \\
\text { 2. } & \text { Partai Karya Peduli } \\
\text { Bangsa (PKPB) } \\
\text { 3. Partai Pengusaha dan } \\
\text { Pekerja Indonesia } \\
\text { (PPPI) } \\
\text { 4. Partai Peduli Rakyat } \\
\text { Nasional (PPRN) } \\
\text { 5. Partai Gerakan } \\
\text { Indonesia Raya } \\
\text { (Gerindra) } \\
\text { 6. Partai Barisan } \\
\text { Nasional (Barnas) }\end{array}$ \\
\hline
\end{tabular}

Perkembangan Politik Hukum ....

121 


\begin{tabular}{|c|c|c|}
\hline No. & \begin{tabular}{|c|} 
Periodisasi \\
Penyeleng- \\
garaan \\
Pemilu \\
\end{tabular} & $\begin{array}{c}\text { Nama-nama Partai } \\
\text { Politik Beserta Nomor } \\
\text { Urut }\end{array}$ \\
\hline & & $\begin{array}{l}\text { 7. Partai Keadilan dan } \\
\text { Persatuan Indonesia } \\
\text { (PKPI) } \\
\text { 8. Partai Keadilan } \\
\text { Sejahtera (PKS) } \\
\text { 9. Partai Amanat } \\
\text { Nasional (PAN) } \\
\text { 10. Partai Perjuangan } \\
\text { Indonesia Baru (PIB) } \\
\text { 11. Partai Kedaulatan } \\
\text { 12. Partai Persatuan } \\
\text { Daerah (PPD) } \\
\text { 13. Partai Kebangkitan } \\
\text { Bangsa (PKB) } \\
\text { 14. Partai Pemuda } \\
\text { Indonesia (PPI) } \\
\text { 15. Partai Nasional } \\
\text { Indonesia } \\
\text { Marhaenisme (PNI } \\
\text { Marhaenisme) } \\
\text { 16. Partai Demokrasi } \\
\text { Pembaruan (PDP) } \\
\text { 17. Partai Karya } \\
\text { Perjuangan (PKP) } \\
\text { 18. Partai Matahari } \\
\text { Bangsa (PMB) } \\
\text { 19. Partai Penegak } \\
\text { Demokrasi Indonesia } \\
\text { (PPDI) } \\
\text { 20. Partai Demokrasi } \\
\text { Kebangsaan (PDK) } \\
\text { 21. Partai Republika } \\
\text { Nusantara } \\
\text { (RepublikaN) } \\
\text { 22. Partai Pelopor } \\
\text { 23. Partai Golongan } \\
\text { Karya (Golkar) } \\
\text { 24. Partai Persatuan } \\
\text { Pembangunan (PPP) } \\
\text { 25. Partai Damai } \\
\text { Sejahtera (PDS) } \\
\text { 26. Partai Nasional } \\
\text { Benteng Kerakyatan } \\
\text { Indonesia (PNBK } \\
\text { Indonesia) } \\
\text { 27. Partai Bulan Bintang } \\
\text { (PBB) }\end{array}$ \\
\hline
\end{tabular}

\begin{tabular}{|c|c|c|}
\hline No. & $\begin{array}{c}\text { Periodisasi } \\
\text { Penyeleng- } \\
\text { garaan } \\
\text { Pemilu }\end{array}$ & $\begin{array}{l}\text { Nama-nama Partai } \\
\text { Politik Beserta Nomor } \\
\text { Urut }\end{array}$ \\
\hline & & $\begin{array}{l}\text { 28. Partai Demokrasi } \\
\text { Indonesia Perjuangan } \\
\text { (PDIP) } \\
\text { 29. Partai Bintang } \\
\text { Reformasi (PBR) } \\
\text { 30. Partai Patriot } \\
\text { 31. Partai Demokrat } \\
\text { 32. Partai Kasih } \\
\text { Demokrasi Indonesia } \\
\text { (PKDI) } \\
\text { 33. Partai Indonesia } \\
\text { Sejahtera (PIS) } \\
\text { 34. Partai Kebangkitan } \\
\text { Nasional Ulama } \\
\text { (PKNU) } \\
\text { 41. Partai Merdeka } \\
\text { 42. Partai Persatuan } \\
\text { Nahdlatul Ummah } \\
\text { Indonesia (PPNUI) } \\
\text { 43. Partai Sarikat } \\
\text { Indonesia (PSI) } \\
\text { 44. Partai Buruh } \\
\text { Partai politik lokal Aceh } \\
\text { meliputi: } \\
\text { 35. Partai Aceh Aman } \\
\text { Seujahtra (PAAS) } \\
\text { 36. Partai Daulat Aceh } \\
\text { (PDA) } \\
\text { 37. Partai Suara } \\
\text { Independen Rakyat } \\
\text { Aceh (SIRA) } \\
\text { 38. Partai Rakyat Aceh } \\
\text { (PRA) } \\
\text { 39. Partai Aceh (PA) } \\
\text { 40. Partai Bersatu Aceh } \\
\text { (PBA) }\end{array}$ \\
\hline 3. & Pemilu 2014 & $\begin{array}{ll}\text { 1. } & \begin{array}{l}\text { Partai Nasional } \\
\text { Demokrat (Partai } \\
\text { Nasdem) }\end{array} \\
\text { 2. } & \begin{array}{l}\text { Partai Kebangkitan } \\
\text { Bangsa (PKB) }\end{array} \\
\text { 3. } & \begin{array}{l}\text { Partai Keadilan } \\
\text { Sejahtera (PKS) }\end{array} \\
\text { 4. } & \begin{array}{l}\text { Partai Demokrasi } \\
\text { Indonesia Perjuangan } \\
\text { (PDIP) }\end{array}\end{array}$ \\
\hline
\end{tabular}




\begin{tabular}{|c|c|c|}
\hline No. & $\begin{array}{c}\text { Periodisasi } \\
\text { Penyeleng- } \\
\text { garaan } \\
\text { Pemilu }\end{array}$ & $\begin{array}{c}\text { Nama-nama Partai } \\
\text { Politik Beserta Nomor } \\
\text { Urut }\end{array}$ \\
\hline & & 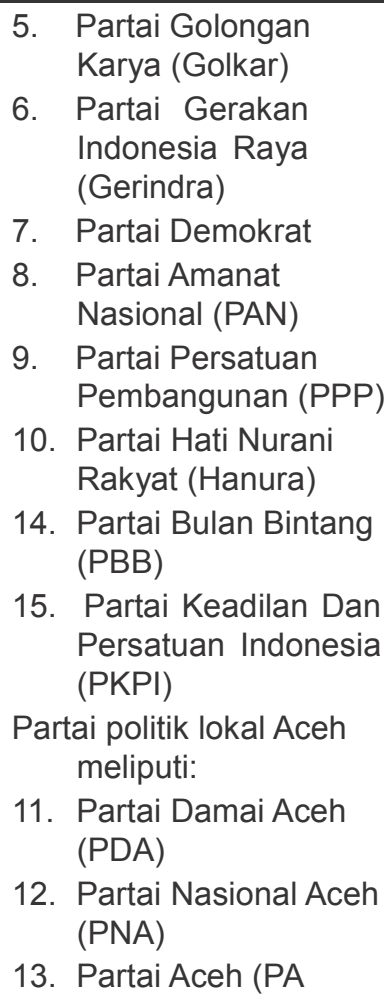 \\
\hline
\end{tabular}

F. Penyelenggaraan Pemilu 2004, produk-produk hukum yang mengatur pertanggungjawaban partai politik dalam pengelolaan bantuan keuangan negara meliputi:

1. UU No. 31 Tahun 2002 tentang Partai Politik meliputi :

- Pasal 17 berbunyi sebagai berikut:

(1) Keuangan partai politik bersumber dari:

a. iuran anggota;

b. sumbangan yang sah menurut hukum; dan

c. bantuan dari anggaran negara.

(2) Sumbangan sebagaimana dimaksud pada ayat (1) huruf b dapat berupa uang, barang, fasilitas, peralatan, dan/atau jasa.

(3) Bantuan sebagaimana dimaksud pada ayat (1) huruf $c$ diberikan secara proporsional kepada partai politik yang mendapatkan kursi di lembaga perwakilan rakyat.

(4) Tata cara penyaluran bantuan sebagaimana dimaksud pada ayat (3) diatur lebih lanjut dengan peraturan pemerintah.

- Pasal 18 berbunyi sebagai berikut:

(1) Sumbangan dari anggota dan bukan anggota sebagaimana dimaksud dalam Pasal 17 ayat (1) huruf b paling banyak senilai Rp200.000.000,00 (dua ratus juta rupiah) dalam waktu 1 (satu) tahun.

(2) Sumbangan dari perusahaan dan/atau badan usaha sebagaimana dimaksud dalam Pasal 17 ayat (1) huruf $b$ paling banyak senilai Rp800.000.000,00 (delapan ratus juta rupiah) dalam waktu 1 (satu) tahun.

(3) Sumbangan sebagaimana dimaksud pada ayat (2) yang diberikan oleh perusahaan dan/atau badan usaha harus dilakukan sesuai dengan ketentuan peraturan perundangundangan.

2. PP No. 29 Tahun 2005 tentang Bantuan Keuangan Kepada Partai Politik meliputi:

- Pasal 2 berbunyi sebagai berikut:

(1) Untuk membantu kegiatan dan kelancaran administrasi dan/atau sekretariat partai politik, Pemerintah memberikan Bantuan Keuangan kepada partai politik.

(2) B antuan Keuangan sebagaimana dimaksud pada ayat (1) diberikan kepada partai politik yang mendapatkan kursi di Lembaga Perwakilan Rakyat hasil Pemilihan Umum Tahun 2004.

(3) Bantuan Keuangan kepada partai politik sebagaimana dimaksud pada ayat (2) diberikan setiap tahun anggaran.

- Pasal 11 berbunyi sebagai berikut:

(1) Laporan penggunaan Bantuan Keuangan kepada partai politik 
tingkat Pusat disampaikan kepada Menteri Dalam Negeri setelah diaudit berdasarkan peraturan perundang-undangan yang berlaku.

(2) Laporan penggunaan Bantuan Keuangan kepada partai politik tingkat Provinsi disampaikan kepada Gubernur setelah diaudit berdasarkan peraturan perundang-undangan yang berlaku.

(3) Laporan penggunaan Bantuan Keuangan kepada partai politik tingkat Kabupaten/ Kota disampaikan kepada Bupati/W alikota setelah diaudit berdasarkan peraturan perundang-undangan yang berlaku.

G. Penyelenggaraan Pemilu 2009, produk-produk hukum yang mengatur pertanggungjawaban partai politik dalam pengelolaan bantuan keuangan negara meliputi:

1. UU No. 11 Tahun 2006 tentang Pemerintahan Aceh

UU No. 11 Tahun 2006 tentang Pemerintahan Aceh secara khusus memuat dan mengatur adanya pendirian partai politik lokal di samping partai politik pada umumnya yang berada di seluruh daerah di Negara Indonesia. Keberadaan partai politik lokal di Aceh ini disebutkan dalam Pasal 75 ayat (1) yang berbunyi bahwa Penduduk di Aceh dapat membentuk partai politik lokal. Partai politik lokal di Aceh juga berkewajiban mempertanggungjawabkan bantuan keuangan dari negara sebagaimana disebutkan dalam Pasal 81 huruf (i) yang berbunyi bahwa Partai politik lokal berkewajiban membuat laporan keuangan secara berkala.

2. PP No. 20 Tahun 2007 tentang Partai Politik Lokal Di Aceh

Disebutkan dalam Pasal 17 yang berbunyi sebagai berikut:

(1) Bantuan keuangan kepada partai politik lokal diberikan secara proporsional berdasarkan perolehan kursi partai politik lokal di DPRA dan/ atau DPRK.
(2) Besaran bantuan keuangan kepada partai politik lokal sebagaimana dimaksud pada ayat (1) tidak melebihi besaran bantuan kepada partai politik nasional.

(3) Bantuan sebagaimana dimaksud pada ayat (2) bersumber dari Anggaran Pendapatan Belanja Aceh (APBA) dan Anggaran Pendapatan Belanja Kabupaten/Kota (APBK).

(4) Ketentuan lebih lanjut mengenai besarnya bantuan, tata cara penyaluran, dan tata cara pertanggungjawaban diatur dengan qanun.

3. UU No. 2 Tahun 2008 tentang Partai Politik meliputi:

- Pasal 1 Angka (5) berbunyi bahwa Partai Politik bahwa keuangan Partai Politik adalah semua hak dan kewajiban Partai Politik yang dapat dinilai dengan uang, berupa uang, atau barang serta segala bentuk kekayaan yang dimiliki dan menjadi tanggung jawab Partai Politik.

- Pasal 34 berbunyi sebagai berikut:

(1) Keuangan partai politik bersumber dari:

a. iuran anggota;

b. sumbangan yang sah menurut hukum; dan

c. bantuan keuangan dari Anggaran Pendapatan dan Belanja Negara/Anggaran Pendapatan dan Belanja Daerah.

(2) Sumbangan sebagaimana dimaksud pada ayat (1) huruf b, dapat berupa uang, barang, dan/atau jasa.

(3) Bantuan keuangan dari Anggaran Pendapatan dan Belanja Negara/Anggaran Pendapatan dan Belanja Daerah sebagaimana dimaksud pada ayat (1) huruf c diberikan secara proporsional kepada Partai Politik yang mendapatkan kursi di Dewan Perwakilan Rakyat, Dewan Perwakilan Rakyat Daerah provinsi, dan Dewan Perwakilan Rakyat Daerah kabupaten/kota yang penghitungannya berdasarkan jumlah perolehan suara. 
(4) Bantuan keuangan kepada Partai Politik sebagaimana dimaksud pada ayat (3) diatur lebih lanjut dengan Peraturan Pemerintah.

- Pasal 36 yang berbunyi sebagai berikut:

(1) Sumber keuangan sebagaimana dimaksud dalam Pasal 34 merupakan pendapatan yang dapat digunakan untuk pengeluaran dalam pelaksanaan program, mencakup pendidikan politik, dan operasional sekretariat Partai Politik.

(2) Penerimaan dan pengeluaran keuangan Partai Politik dikelola melalui rekening kas umum Partai Politik.

(3) Pengurus Partai Politik di setiap tingkatan melakukan pencatatan atas semua penerimaan dan pengeluaran keuangan Partai Politik.

- Pasal 37 berbunyi bahwa Pengurus Partai Politik di setiap tingkatan organisasi menyusun laporan pertanggungjawaban penerimaan dan pengeluaran keuangan setelah tahun anggaran berkenaan berakhir.

- Pasal 38 berbunyi bahwa Hasil pemeriksaan laporan pertanggungjawaban penerimaan dan pengeluaran keuangan Partai Politik sebagaimana dimaksud dalam Pasal 37 terbuka untuk diketahui masyarakat.

- Pasal 39 berbunyi bahwa Pengelolaan keuangan Partai Politik diatur lebih lanjut dalam AD dan ART.

4. PP No. 5 Tahun 2009 tentang Bantuan Keuangan Kepada Partai Politik meliputi:

- Pasal 12 berbunyi sebagai berikut:

(1) Partai Politik wajib membuat laporan pertanggungjawaban penerimaan dan pengeluaran keuangan yang bersumber dari dana bantuan APBN/APBD.

(2) Untuk membuat Iaporan pertanggungjawaban sebagaimana dimaksud pada ayat (1), Partai Politik wajib melaksanakan pembukuan dan memelihara bukti penerimaan dan pengeluaran atas dana bantuan keuangan.

- Pasal 13 berbunyi bahwa Partai Politik wajib menyampaikan laporan pertanggungjawaban penerimaan dan pengeluaran keuangan yang bersumber dari dana bantuan APBN/ APBD secara berkala 1 (satu) tahun sekali kepada Pemerintah setelah diperiksa oleh Badan Pemeriksa Keuangan.

- Pasal 14 berbunyi sebagai berikut:

(1) Laporan pertanggungjawaban sebagaimana dimaksud dalam Pasal 13 disampaikan kepada:

- Pemerintah melalui Menteri Dalam Negeri oleh Partai Politik tingkat pusat;

- gubernur oleh Partai Politik tingkat provinsi; dan

- bupati/walikota oleh Partai Politik tingkat kabupaten/ kota.

(2) Laporan pertanggungjawaban sebagaimana dimaksud pada ayat (1) disampaikan paling lambat 1 (satu) bulan setelah diperiksa Badan Pemeriksa Keuangan.

- Pasal 15 berbunyi bahwa Laporan pertanggungjawaban sebagaimana dimaksud dalam Pasal 13 terbuka untuk diketahui masyarakat.

- Pasal 16 berbunyi bahwa Partai Politik yang melanggar ketentuan sebagaimana dimaksud dalam Pasal 13 dikenai sanksi administratif berupa penghentian bantuan keuangan APBN/APBD sampai laporan diterima oleh Pemerintah dalam tahun anggaran berkenaan.

H. Penyelenggaraan Pemilu 2014, produk-produk hukum yang mengatur pertanggungjawaban partai politik dalam pengelolaan bantuan keuangan negara meliputi:

1. UU No. 2 Tahun 2011 tentang Perubahan Atas UU No. 2 Tahun 2008 tentang Partai Politik meliputi:

- Pasal 34 berbunyi sebagai berikut:

(1) Keuangan partai politik bersumber dari: 
a. iuran anggota;

b. sumbangan yang sah menurut hukum; dan

c. bantuan keuangan dari Anggaran Pendapatan dan Belanja Negara/Anggaran Pendapatan dan Belanja Daerah.

(2) Sumbangan sebagaimana dimaksud pada ayat (1) huruf b, dapat berupa uang, barang, dan/atau jasa.

(3) Bantuan keuangan dari Anggaran Pendapatan dan Belanja Negara/Anggaran Pendapatan dan Belanja Daerah sebagaimana dimaksud pada ayat (1) huruf c diberikan secara proporsional kepada Partai Politik yang mendapatkan kursi di Dewan Perwakilan Rakyat, Dewan Perwakilan Rakyat Daerah provinsi, dan Dewan Perwakilan Rakyat Daerah kabupaten/kota yang penghitungannya berdasarkan jumlah perolehan suara.

a) Bantuan keuangan dari Anggaran Pendapatan dan Belanja Negara/Anggaran Pendapatan dan Belanja Daerah sebagaimana dimaksud pada ayat (3) diprioritaskan untuk melaksanakan pendidikan politik bagi anggota Partai Politik dan masyarakat.

b) Pendidikan Politik sebagaimana dimaksud pada ayat (3a) berkaitan dengan kegiatan:

a. pendalaman mengenai empat pilar berbangsa dan bernegara yaitu Pancasila, UUD 1945, Bhinneka Tunggal Ika dan Negara Kesatuan Republik Indonesia;

b. pemahaman mengenai hak dan kewajiban warga negara Indonesia dalam membangun etika dan budaya politik; dan

c. pengkaderan anggota Partai Politik secara berjenjang dan berkelanjutan.
(4) Bantuan keuangan dan laporan penggunaan bantuan keuangan kepada Partai Politik sebagaimana dimaksud pada ayat (3) dan (3a) diatur lebih lanjut dengan Peraturan Pemerintah.

- Pasal 34A berbunyi sebagai berikut:

(1) Partai Politik wajib me-

nyampaikan laporan pertanggungjawaban penerimaan dan pengeluaran yang bersumber dari dana bantuan Anggaran Pendapatan dan Belanja Negara dan Anggaran Pendapatan dan Belanja Daerah sebagaimana dimaksud dalam Pasal 34 ayat (1) huruf c kepada Badan Pemeriksa Keuangan secara berkala 1 (satu) tahun sekali untuk diaudit paling lambat 1 (satu) bulan setelah tahun anggaran berakhir.

(2) Audit laporan sebagaimana dimaksud pada ayat (1) dilakukan 3 (tiga) bulan setelah tahun anggaran berakhir.

(3) Hasil audit atas laporan pertanggungjawaban penerimaan dan pengeluaran sebagaimana dimaksud pada ayat (2) disampaikan kepada Partai Politik paling lambat 1 (satu) bulan setelah diaudit.

- Pasal 39 berbunyi sebagai berikut:

(1) Pengelolaan keuangan Partai Politik dilakukan secara transparan dan akuntabel.

(2) Pengelolaan keuangan Partai Politik sebagaimana dimaksud pada ayat (1) diaudit oleh akuntan publik setiap 1 (satu) tahun dan diumumkan secara periodik.

(3) Partai Politik wajib membuat laporan keuangan untuk keperluan audit dana yang meliputi:

a. laporan realisasi anggaran Partai Politik;

b. laporan neraca; dan

c. laporan arus kas.

2. PP No. 83 Tahun 2012 tentang Perubahan Atas PP No. 5 Tahun 2009 tentang 
Bantuan Keuangan Kepada Partai Politik meliputi:

- Pasal 12A berbunyi sebagai berikut:

(1) Partai Politik wajib menyampaikan laporan pertanggungjawaban penerimaan dan pengeluaran bantuan keuangan yang bersumber dari dana APBN dan APBD kepada BPK secara berkala 1 (satu) tahun sekali untuk diperiksa paling lambat 1 (satu) bulan setelah tahun anggaran berakhir.

(2) Pemeriksaan atas laporan pertanggungjawaban penerimaan dan pengeluaran sebagaimana dimaksud pada ayat (1) sudah selesai dilakukan oleh BPK paling lama 3 (tiga) bulan setelah tahun anggaran berakhir.

(3) Ketentuan lebih lanjut mengenai tata cara penyampaian laporan oleh Partai Politik kepada BPK sebagaimana dimaksud pada ayat (1) dan tata cara penyampaian laporan hasil pemeriksaan oleh BPK kepada Partai Politik sebagaimana dimaksud pada ayat (3) diatur dengan peraturan BPK.

(4) Ketentuan lebih lanjut mengenai tata cara penyampaian laporan oleh Partai Politik kepada BPK sebagaimana dimaksud pada ayat (1) dan tata cara penyampaian laporan hasil pemeriksaan oleh BPK kepada Partai Politik sebagaimana dimaksud pada ayat (3) diatur dengan peraturan BPK.

- Pasal 13 berbunyi bahwa Partai Politik wajib menyampaikan laporan pertanggungjawaban penerimaan dan pengeluaran keuangan yang bersumber dari dana bantuan APBN dan APBD secara berkala
1 (satu) tahun sekali kepada pemerintah setelah diperiksa oleh BPK sebagaimana dimaksud dalam Pasal 12A.

\section{Simpulan}

Berdasarkan uraian yang telah dipaparkan, maka dapat disimpulkan beberapa hal sebagai berikut:

1. Politik hukum pertanggungjawaban partai politik dalam pengelolaan bantuan keuangan negara adalah suatu kebijakan hukum (legal policy) negara untuk mencapai tujuan nasionalnya dengan membentuk hukum berupa peraturan perundang-undangan untuk mengatur pertanggungjawaban partai politik dalam mengelola bantuan keuangan negara.

2. Pasca reformasi politik hukum tersebut menunjukkan perkembangan jika ditinjau dari periodisasi penyelenggaraan pemilu secara langsung di Negara Republik Indonesia, yaitu: Pemilu 2004, 2009, dan 2014.

3. Penyelenggaraan Pemilu 2004, produk-produk hukum yang mengatur pertanggungjawaban partai politik dalam pengelolaan bantuan keuangan negara meliputi: UU No. 31 Tahun 2002 tentang Partai Politik dan PP No. 29 Tahun 2005 tentang Bantuan Keuangan Kepada Partai Politik.

4. Penyelenggaraan Pemilu 2009, produk-produk hukum yang mengatur pertanggungjawaban partai politik dalam pengelolaan bantuan keuangan negara meliputi: UU No. 11 Tahun 2006 tentang Pemerintahan Aceh, PP No. 20 Tahun 2007 tentang Partai Politik Lokal Di Aceh, UU No. 2 Tahun 2008 tentang Partai Politik, dan PP No. 5 Tahun 2009 tentang tentang Bantuan Keuangan Kepada Partai Politik.

5. Penyelenggaraan Pemilu 2014, produk-produk hukum yang mengatur pertanggungjawaban partai politik dalam pengelolaan bantuan keuangan negara meliputi: UU No. 2 Tahun 2011 tentang Perubahan Atas UU No. 2 Tahun 2008 tentang Partai Politik dan PP No. 83 Tahun 2012 tentang Perubahan Atas PP No. 5 Tahun 2009 tentang Bantuan Keuangan Kepada Partai Politik. 


\section{Daftar Pustaka}

Abdul Mukthie Fadjar. 2008. Partai Politik Dalam Perkembangan Sistem Ketatanegaraan Indonesia. Cetakan Pertama. Malang: In-TRANS Publising.

Amal Ichlasul (editor). 1998. Teori-Teori Mutakhir Partai Politik. Yogyakarta: PT. Tiara Wacana.

C. F. G. Sunaryati Hartono. 1991. Politik Hukum, Menuju Satu Sistem Hukum Nasional. Bandung: Alumni.

Didik Supriyanto. 2012. Kebijakan Bantuan Keuangan Partai Politik: Review terhadap PP No. 5/2009 dalam Rangka Penyusunan Peraturan Pemerintah Baru Berdasar UU No. 2/2011, dalam "Dana Kampanye: Pengaturan Tanpa Makna", Jurnal Perludem Volume 3 Mei.

Emmy Hafild. 2008. Laporan Studi: Standar Akuntansi Keuangan Khusus Partai Politik. Cetakan Kedua, Jakarta: Transparency International Indonesia dan IFES.

Moh. Mahfud MD. 2010. Membangun Politik Hukum, Menegakkan Konstitusi, Cetakan Pertama, Jakarta: PT. RajaGrafindo Persada.

Padmo Wahjono. 1986. Indonesia Negara Berdasakan atas Hukum, Jakarta: Ghalia Indonesia.

1991. Menyelisik Proses Terbentuknya Perundang-Undangan. artikel dalam Majalah Forum Keadilan No. 29 April.

Ramlan Surbakti. 1999. Memahami Ilmu Politik, Jakarta: Grasindo.

Sidik Pramono. 2011. Pengendalian Keuangan Partai Politik, Jakarta: Kemitraan Bagi Pembaruan Tata Pemerintahan.

Satjipto Rahardjo. 1991. Ilmu Hukum, Cetakan Ketiga, Bandung: Citra Aditya Bakti.

Soedarto. 1983. Hukum Pidana dan Perkembangan Masyarakat Kajian Terhadap Hukum Pidana, Bandung: Sinar Baru.

Teuku Mohammad Radhie. 1973. "Pembaharuan dan Politik Hukum dalam Rangka Pembangunan Nasional". artikel dalam Majalah Prisma Nomor 6 Tahun II Desember. 